\title{
Endurskoðunarnefndir: Gagnsæi og traust til fjárhagsupplýsinga
}

\author{
Einar Guðbjartsson, Eypór Ívar Jónsson og Jón Snorri Snorrason ${ }^{1}$
}

\begin{abstract}
Ágrip
Einn mest áberandi páttur í góðum stjórnarháttum síðustu tvo áratugina hefur verið endurskoðunarnefnd, sem fer með hluta af störfum sem stjórn hafði áđur á sínu borði. Endurskoðunarnefnd er m.a. ætlað pað hlutverk að auka traust almennings á fjárhagslegum upplýsingum á almennum fjármagnsmarkaði. Gagnsæi og traust eykst ekki sjálfkrafa. Vandaðir og heiðarlegir starfshættir eru nauðsynlegir til pess аð öðlast traust haghafa. Rannsókn pessi felur í sér spurninguna um hvort að endurskoðunarnefndir auki gagnsæi og traust á fjárhagsupplýsingum fyrirtækja.

Greinin byggir á tveimur könnunum, annars vegar frá 2016 par sem nefndarmenn endurskoðunarnefnda í einingum tengdum almannahagsmunum voru pátttakendur og hins vegar frá 2018 par sem ytri endurskoðendur voru pátttakendur. Í greininni er fjallað um afstöðu og álit pátttakenda varðandi tilkomu endurskoðunarnefnda gagnvart gagnsæi og trausti m.t.t. fjárhagsupplýsinga. Slík rannsókn hefur ekki verið gerð áđur á Íslandi.

Tilgátur voru settar fram um hvað væri álit og afstaða hópanna varðandi tilkomu endurskoðunarnefnda. Niðurstöður eru m.a. að meirihluti nefndarmanna og ytri endurskoðendur telja að bæði gagnsæi og traust hafi aukist með vinnuframlagi nefndarmanna í endurskoðunarnefndum.

Pað vekur pó athygli í rannsókninni að niðurstaðan er ekki eins afgerandi og ætla hefði mátt, p.e. stór hópur bæði nefndarmanna og ytri endurskoðenda telur að tilkoma endurskoðunarnefnda hafi ekki aukið gagnsæi og traust m.t.t. fjárhagsupplýsinga. Sú niðurstaða kallar á frekari rannsóknir, t.d. með pví að spyrja fleiri hagaðila um álit peirra á endurskoðunarnefndum og hlutverki peirra í að auka gagnsæi og traust. Petta kallar enn fremur á rannsóknir sem miða að pví að meta markvirkni endurskoðunarnefnda í stjórnarháttarkerfi fyrirtækja tengdum almannahagsmunum.
\end{abstract}

\section{Abstract}

One of the most prominent aspects of good governance over the last two decades has been the Audit Committee, which handles some of the tasks previously held by the Board. The Audit Committee is i.a. intended to increase public confidence in financial information in the general capital market. Transparency and trust do not increase automatically. Careful and honest practices are essential to gaining

1 Einar Guðbjartsson er dósent í viðskiptafræði við Háskóla Íslands. Netfang: eg@hi.is. Eypór Ívar Jónsson er lektor við Viðskiptaháskólann í Kaupmannahöfn. Netfang: eythor@akademias.is. Jón Snorri Snorrason er dósent við viðskiptadeild Háskólans á Bifröst. Netfang: jonsnorri@bifrost.is.

This work is licensed under a Creative Commons Attribution 4.0 License.

DOI: https://doi.org/10.24122/tve.a.2021.18.2.6

(C) Tímarit um viðskipti og efnahagsmál

www.efnahagsmal.is 
the trust of stakeholders. This study raises the question of whether effective audit committees increase transparency and trust in company financial information.

The article is based on two surveys, on the one hand from 2016 where the members of the audit committees in entities related to the public interest were participants and on the other hand from 2018 where external auditors of those entities were participants. The article discusses the attitudes and opinions of participants regarding the establishment of audit committees regarding transparency and trust regarding financial information. Such a study has not been conducted before in Iceland.

Hypotheses were put forward as to the opinion of the groups regarding the establishment of audit committees. The results are i.a. that the majority of committee members and external auditors believe that both transparency and trust have increased with the work of committee members in audit committees.

What draws attention to the study, however, is that the result is not as decisive as might have been expected, ie. a large group of both committee members and external auditors believe that the establishment of audit committees has not increased transparency and trust with regard to financial information. That conclusion calls for further research, e.g. by asking more stakeholders about their views on audit committees and their role in increasing transparency and trust. This also calls for research aimed at assessing the effectiveness of audit committees in the governance system of public interest entities.

JEL flokkun: M420, K220

Lykilorð: reikningsskil, endurskoðun, endurskoðunarnefndir, gagnsæi, traust, lög um ársreikninga, einingar tengdar almannahagsmunum, góðir stjórnarhættir fyrirtækja, umboðskenning.

Keywords: accounting, auditing, audit committees, transparency, trust, accounting act, public interest entity, corporate governance, agency theory.

\section{Audit committees: Transparency and trust regarding financial information}

\section{Inngangur}

Umhverfi upplýsingagjafar (e. information environment) er mjög mikilvægt fyrir fjárfesta, markaði sem og allt samfélagið. Jafnt aðgengi að upplýsingum er forsenda pess að jafnræði ríki á milli innri og ytri aðila fyrirtækja (Frankel og Li, 2004). Í umhverfi par sem gagnsæi er til staðar ætti verð hlutabréfa að vera meira upplýsandi um atburði í framtíðinni, par af leiðir ættu upplýsingar í framtíðinni að koma minna á óvart (Dasgupta o.fl., 2010). Starfshættir endurskoðunarnefnda leggja grunninn að bættu umhverfi til upplýsingagjafa (Ghosh, 2019). Gagnsæi er meira en upplýsingar á blaði. Framkvæmdarfyrirkomulag á pví hvernig gerð og framsetningu reikningsskila er háttað hefur áhrif á gagnsæi, t.d. hvaða upplýsingar eru settar fram, hvenær og hvernig. Í rannsókn frá 2011 kom fram að afkomuspár vegna markaðsgreininga eru réttari og nákvæmari (e. more accurate and less dispersed) pegar nefndarmaður í endurskoðunarnefnd hefur fjármálasérhæfingu (e. financial expertise) (Abernathy, Kang og Gopal, 2011). Traust tengist pví efni sem birt hefur verið. Traust er áunnið en ekki búið til. Stjórnir viðkomandi félaga skipa endurskoðunarnefndir, val nefndarmanna og uppbygging eru pví mikilvæg atriði (Einar Guðbjartsson o.fl., 2018). Góðir stjórnarhættir eru pví lykilatriði við val nefndarmanna og uppbyggingu nefndanna. Með tilskipun Evrópuráðsins frá 2014 (EU, 2014) hefur starfsumfang verið aukið til muna og par með væntingar fjármagnsmarkaðarins og almennings til hlutverks endurskoðunarnefnda gagnvart samfélaginu.

Í grein eftir Wang o.fl. frá 2016 er (of lítið) gagnsæi upplýsinga tengt rangri upplýs- 
ingagjöf til markaðarins í Taiwan. Með rangri upplýsingagjöf er hér átt við ólögmætar eignatilfærslur (e. embezzled company assets) og uppblásinn hagnað (e. inflated company earnings). Niðurstöður sýna jákvætt samband á milli endurskoðunarnefnda og gagnsæi upplýsinga sem og gæði hagnaðar (e. earnings quality) (Lin o.fl., 2006). Í grein frá 2007, eftir Jo og Kim, er komist að peirri niðurstöðu að gagnsæi í upplýsingum geti dregið úr fyrirfram ákveðnum hagnaði (e. earnings management). Í grein Ashbaugh-Skaife o.fl. frá 2008, kemur fram að gæði hagnaðar eru nátengd innra eftirliti (e. internal control). Eitt af verkefnum endurskoðunarnefndar skv. lögum er að hafa eftirlit með virkni innra eftirlits. Birta upplýsingar, aukið gagnsæi, um innra eftirlit af hálfu endurskoðunarnefnda hefur pví áhrif á gæði hagnaðar og par með ætti traust að aukast.

Samkvæmt Bushman o.fl. (2004) er gagnsæi skipt í tvennt, gagnsæi tengt stjórnarháttum og gagnsæi tengt fjárhagsupplýsingum. Рað er sinn hvor áhrifavaldurinn á gagnsæi eftir pví hvort talað er um stjórnarhætti eða fjárhagsupplýsingar. Gagnsæi fjárhagsupplýsinga tengist aðallega stjórnmálaaðstæðum á hverjum stað en gagnsæi tengt stjórnarháttum tengist aðallega laga- og dómstólaumhverfinu. Gagnsæi hefur mörg gleraugu. Í grein eftir Ball (2009) er rætt um tvö hugtök, annars vegar gagnsæi og reikningsskilaskylda (e. accountability). Par er gagnsæi skipt upp í prjár myndlíkingar, eftir pví hvaða aðstæðum er verið að lýsa, hagsmunir almennings (e. public value), opin ákvörðunartaka (e. open descision-making) og góðir stjórnarhættir (e. good governance). Fyrsta myndlíkingin snertir reikningsskil að hluta og að öll reikningsskil eigi að gefa glögga mynd af rekstri og fjárhag.

Opinber fjárhagsskýrslugjöf hefur fengið gagnrýni fyrir of lítið gagnsæi. Spurðir voru um 10.000 einstaklingar í 10 löndum, um 20\% voru ánægð með fjárhagsskýrslur og upplýsingagjöf opinberra aðila. Ástæða pess að gagnsæi og traust hefur mikla pýðingu fyrir opinber fjármál. (ICAW og PwC, 2015).

Greater transparency and comparability will help to underpin informed debate on the use of public monies. This is a key feature of democratic accountability, a process which requires strong political commitment backed by greater scrutiny by citizens, media and markets.

Gagnsæi næst ekki með pví einvörðungu að fylla í boxið og segja að öll ákvæði séu uppfyllt. Рað verður að vera fagleg dómgreind sem liggur par til grundvallar, p.e. hvort nefndirnar geri pað sem pær eiga og segjast gera (Carcello o.fl., 2002).

Grundvallaratriði er að traust geti hjálpað til við að efla stjórnarhætti með pví að auka skilvirkni eftirlits og að koma í veg fyrir freistnivanda og tækifærismennsku (Puranam og Vanneste, 2009). Traust geti jafnvel aukið skilvirkni formlegs eftirlits með pví að gera eftirlitið einfaldara og meira viðurkennt en á sama tíma draga úr mikilvægi pess (Poppo og Zenger, 2002; Puranam og Vanneste, 2009). Pannig styður traust við eftirlitspætti eins og samninga o.fl. (Poppo og Zenger, 2002; Woolthuis, Hillebrand og Nooteboom, 2005). Á hinn bóginn getur traust að einhverju leyti komið í stað formlegs eftirlits (Bradach og Eccles, 1989; Mayer o.fl. , 1995). En bæði traust og stjórnarhættir snúast um langtímasamband aðila (Gulati, Lawrence og Puranam, 2005; Williamson, 1991). Traust getur jafnframt dregið úr kostnaði við eftirlitspátt formlegra stjórnarhátta (Bradach og Eccles, 1989). Sumir fræðimenn hafa ennfremur bent á pann möguleika að formlegir stjórnarhættir geti í raun dregið úr möguleika á að traust skapist milli aðila par sem sambandið er pá háð samningum og flóknu samspili stjórnarhátta (Malhotra og Murnigham, 2002). Pannig er samspil trausts og stjórnarhátta hugsanlega flóknara en grundvallarhugmynd stjórnarhátta út frá umboðskenningu gefur til kynna (Puranam og Vanneste, 2009). Segja má að traust geti verið leið til pess að sjá af hverju aðrar kenningar, eins og stewardship kenningin, sem leggja áherslu á samvinnu aðila sem tengjast stjórnarháttum frekar en eftirlit hafi svar við freistnivandanum. 
Samkvæmt skoðunarkönnun sem CAQ gerði 2019 pá hefur traust til endurskoðunarnefnda aukist um 10\% frá pví byrjað var að gera pessar kannanir, Barometer report, 2014. Раð kemur einnig fram að með auknu gagnsæi á ábyrgðarsviði endurskoðunarnefnda pá geti traust einnig aukist enn meir. Pessi tvö hugtök eru pví samofin.Upphaf umræðu um stjórnarhætti er yfirleitt rakið til umræðu Berle og Means (1932) um yfirráð og eftirlit með framkvæmdastjórum fyrirtækja. Greining Berle og Means (1932) á umboðslausum yfirráđum stjórnenda fyrirtækja lagði grunninn að stjórnarháttum sem tæki til pess að hafa eftirlit með freistnivanda stjórnenda (Ulhøi, 2007; Lubatkin, 2007). Раð má líka segja að áhugi á stjórnarháttum sé yfirleitt tengdur mistökum og svikum í fyrirtækjarekstri. Fjármálakreppan 2007 - 2009 hafði mikil áhrif á umræðu um stjórnarhætti og hafa fræðimenn ályktað að rekja megi orsakir kreppunnar að miklu leyti til mistaka og veikleika stjórnarhátta fyrirtækja (Kirkpatrick, 2009).

Umboðskenningin sem rakin er til umræðu Berle og Means (1932) er jafnframt sú kenning sem er algengasti útgangspunktur umræðu um stjórnarhætti (Stiles og Taylor, 2001). Umboðskenningin leggur út frá peirri tilgátu að stjórnendur muni ekki alltaf vinna með hagsmuni hluthafa félagsins að leiðarljósi og par af leiðandi purfi hluthafar að hafa einhverja vernd gagnvart pessum eiginhagsmunum stjórnenda (Fama, 1980; Fama og Jensen, 1983; Jensen og Meckling, 1976). Hlutverk stjórnar samkvæmt tilgátu umboðskenningarinnar er að verja hagsmuni hluthafa og hafa eftirlit með stjórnendum félagsins, framgangi og sampykktri stefnu félagsins (Stiles og Taylor, 2001, DeZoort o.fl., 2002).

Erlendar rannsóknir á stjórnarháttum og endurskoðunarnefndum benda til pess að endurskoðunarnefndir séu mjög mikilvægar til pess að tryggja góða stjórnarhætti út frá umboðskenningunni. Endurskoðunarnefndir auka verkaskiptingu stjórna og leggja áherslu á reikningsskil, endurskoðun, áhættustjórnun og innra eftirlit (BRC, 1999; Burke og Guy, 2001; Rittenberg og Nair, 1993). Endurskoðunarnefndir eiga að tryggja gæði pessara pátta, sérstaklega gæði reikningsskila.

Með petta að leiðarljósi er nauðsynlegt að fá álit fagaðila sem vinna með hugtökin gagnsæi og traust við gerð og framsetningu reikningsskila. Pessir aðilar eru nefndarmenn endurskoðunarnefnda og ytri endurskoðendur. Báðir pessir markhópar purfa að leggja faglegt mat á reikningsskil. Petta faglega mat á að hjálpa haghöfum að skilja reikningsskilin, gera pau gagnsæ og ávinna traust.

Rannsóknarspurningin er: Hefur traust og gagnsæi á fjárhagsupplýsingum aukist með tilkomu endurskoðunarnefnda? Markmið greinarinnar er að fjalla um álit nefndarmanna í endurskoðunarnefndum annars vegar og ytri endurskoðenda hins vegar hvað varðar hugtökin gagnsæi og traust með tilliti til fjárhagsupplýsinga eininga tengdum almannahagsmunum.

\section{Endurskoðunarnefndir, gagnsæi og traust}

\subsection{Endurskoðunarnefndir}

Reikningsskil á Evrópska efnahagssvæðinu eru hugtakatengd, p.e. meginreglan gildir. Kemur petta mjög skýrt fram í hugtakaramma IASB, 2018 (e. Conceptual Framework for Financial Reporting). Hugtakaskýringar og skilningur eru pví mikilvægur páttur í gerð og framsetningu reikningsskila tengt Evrópska efnahagssvæðinu. Vegna pessa er mikilvægt að hafa vitneskju um рað hvernig fagaðilar skilja mikilvæg hugtök innan reikningsskila Mismunandi skilningur á hugtökum getur haft í för með sér misræmi á framsetningu reikningsskila. Pessi grein tekur fyrir tvö hugtök er tengjast fjárhagsupplýsingum og -skýrslum, p.e. gagnsæi (e. transparency) og traust (e. trust). Hugtökin hafa verið mjög áberandi sl. tvo áratugi hvað varðar gerð og framsetningu reikningsskila. Hugtökin tengjast mjög starfi endurskoðunarnefnda par sem tilkoma peirra eykur traust og gagnsæi fjárhagsupplýsinga eftir laskaðan fjármálamarkað.

Endurskoðunarnefndir eru að verða eitt af aðalatriðunum í góðum stjórnarháttum í fyrirtækjum í dag. Staða endurskoðunarnefnda í samfélaginu fer m.a. eftir próun í Evr- 
ópusambandinu, vilja stjórnvalda, fagaðila sem og markaðarins sem heild. Endurskoðunarnefnd er eina undirnefnd stjórnar sem er lagaboðin, skv. ársreikningalögum, aðrar nefndir eru valfrjálsar. Lagaskyldan hlýtur að lýsa mikilvægi pess að rétt sé staðið að uppbyggingu, m.a. vali nefndarmanna. Endurskoðunarnefnd verður veikburða ef nefndarmenn hafa ekki hæfi eða hæfni til að takast á við pau verkefni sem ætlast er til. Óhæði nefndarmanna er oftar en ekki lykilatriði í rannsóknum um sjálfstæði og hlutverk endurskoðunarnefnda. En niðurstöður eru ekki afdráttarlausar varðandi sjálfstæði endurskoðunarnefnda og gæði reikningsskila (Pomeroy og Thornton, 2008).

Starfsumfang endurskoðunarnefnda hefur aukist mjög mikið síðustu árin sem og mikilvægi peirra. Flækjustig reikningsskila hefur einnig aukist frá ári til árs. Flækjustig einstakra liða í reikningsskilum hafa aukist mun meira umfram annarra, t.d. fjármálagerningar (ACCA, 2008). Alpjóðlegir reikningsskilastaðlar (International Financial Reporting Standards [IFRS]) stuðla að gagnsæi, m.a. með alpjóðlegum samanburði og gæði fjárhagsupplýsinga. Petta gerir fjárfestum og öðrum markaðsaðilum kleift að taka upplýstar efnahagslegar ákvarðanir og stuðlar að skilvirkari fjármagnsmarkaði (IFRS, 2018). Mikilvægi ófjárhagslega upplýsinga (e. non-financial information) hefur aukist mjög í reikningsskilum fyrirtækja og stofnana. Má nefna hér alpjóðlegu reikningsskilastaðlana IRFS 7 og IFRS 14 sem og t.d. óefnislegar eignir, réttindi hvers konar, ákvæði í lánasamningum, starfsmannastefna, loftlagsstefna, stjórnunarstefna. Gagnsæi og traust byggist á pví að upplýsa um efnisatriði er hafa áhrif á mat priðja aðila varðandi fjárhagslega stöðu sem og rekstrarárangur einingarinnar til framtíðar litið. Endurskoðunarnefndir eru í kjörstöðu til að vinna að auknu gagnsæi og trausti.

Evrópusambandið gaf út 2019 leiðbeinandi tilmæli (EU, 2019) varðandi upplýsingar er tengjast loftlagsbreytingum sem eru ófjárhagsleg atriði (e. non-financial issues). Eru pessar leiðbeiningar tengdar við Parísar samkomulagið 2015. Í inngangi að leiðbeiningunum er m.a. rætt um pann ávinning sem hlýst af pví að upplýsa um áhrif sem fyrirtækið hefur á umhverfi sitt. Pessi umræða getur til og með lækkað fjármagnskostnað (e. cost of capital) og stuðlað аð betri samskiptum við haghafa t.d. hluthafa og fjármálastofnanir. Reikningsskil er viðurkennt samskiptaverkfæri á milli stjórnar og hluthafa, pví er nákvæmni og áreiðanleiki mjög mikilvæg atriði. Skortur á upplýsingum leiðir til pess að traust minnkar og dregur úr gagnsæi.

Fjármálastofnanir nota og skoða meira skýringar sem fylgja með reikningsskilum við mat á lánshæfi, t.d. aldurdreifingu viðskiptakrafna, ástæða fyrir virðisbreytingu eigna. Um pessi samskipti gilda ákveðin viðmið, t.d. alpjóðlegir reikningsskilastaðlar. Pess vegna er mikilvægt að í reikningsskilum sé nákvæm og rétt „frásögn“, p.e. að glögg mynd náist. Par sem flækjustig rekstrarumhverfis fyrirtækja hefur aukist á síðustu áratugum pá eykst einnig erfiðleikastig við gerð og framsetningu reikningsskila. Gerð og framsetning reikningsskila aðlagast rekstrar-, fjármála- og skattaumhverfi fyrirtækja á hverjum tíma. (FEI, 2010).

Ísland fylgir Evrópusambandinu hvað varðar lög, reglugerðir og/eða tilmæli um endurskoðunarnefndir. Aðildarríki Evrópusambandsins og pau ríki er tilheyra EES samningnum hafa ákveðið svigrúm til að aðlaga ákveðnar reglur að staðháttum og umhverfi sínu. Lagaákvæði um endurskoðunarnefndir er að finna í lögum um ársreikninga nr. 3/2006, en pau voru sett við breytingu á lögunum sem tók gildi 1. janúar 2009.

Opinberir aðilar hafa undanfarinn áratug styrkt stöðu endurskoðunarnefnda til að stuðla að betri reikningsskilum, upplýsingagjöf, gagnsæi fjárhagsupplýsinga og auknum gæðum endurskoðunar með samskiptum og umsjón með ytri endurskoðendum. Má nefna atriði eins og beint samtal við endurskoðanda án aðkomu framkvæmdarstjórnar, verður að sampykkja pjónustu sem ekki er endurskoðun sem endurskoðandi má veita fyrirtækinu (non-audit service), fjárhagur endurskoðunarnefnda verður að endurspegla umfang nefndar og frásögn í reikningsskilum um pau verkefni sem nefndin vann að á viðkomandi ári (SEC, 2002; EU, 2016). 
Endurskoðunarnefndir hafa meiri áhrif gagnvart stjórnarháttum í samanburði við aðrar nefndir og aðra starfsemi stjórnar. Endurskoðunarnefnd hefur vissa valda- og áhrifastöðu (Hambrick og Mason, 1984; Finkelstein, 1992; Sharma o.fl. 2009). Jafnframt pykir stjórnarmaður sem er formaður endurskoðunarnefndar vera áhrifameiri en aðrir stjórnarmenn sem eru ekki formenn nefnda (Udueni, 1999). Formenn nefnda hafi bæði vald í formi áhrifavalds og sérfræðivalds (Beasley o.fl. 2009). Á Íslandi eru formenn endurskoðunarnefnda yfirleitt óháđir félaginu.

\subsection{Gagnsæi}

Mikilvægi gagnsæis fyrir fjárfesta er mun meira í dag en fyrir tuttugu árum. Ástæða pess að álit nefndarmanna er mikilvægt er sú að óformlegt net á milli nefndarmanna í endurskoðunarnefndum hafa mjög mikil áhrif á próun góðra stjórnarhátta (Turley og Zaman, 2007). Samkvæmt Ajinkya o.fl. (2005) geta góðir stjórnarhættir stuðlað að gagnsærri upplýsingagjöf. ACCA (2014) fjalla um góða stjórnarhætti og árétta mikilvægi gagnsæis með pví að vitna í reglur um góða stjórnarhætti í Bretlandi er beinast að endurskoðunarnefndum. Í grein eftir Kelton og Yang frá 2008 er bent á að tíðni funda og sjálfstæði endurskoðunarnefnda í pví að birta sjálfviljugar fjárhagsupplýsingar og pannig bæta gagnsæi til priðja aðila. Gagnsæi upplýsingagjafar fyrirtækja er tengt aðferð pess við miðlun upplýsinga, (Bushman o.fl. 2004). Par er að finna skilgreiningu á pví hvað er gagnsæi; víðtækt aðgengi að upplýsingum fyrir pá sem standa utan við fyrirtækið (Bushman o.fl., 2004).

Gagnsæi er ekki tengt magni af fjárhagsupplýsingum heldur ber að tengja pað t.d. tímabærni (e. timeliness), vægi (e. relevance), heilpekjandi (e. completeness) og áreiðanleika (e. reliability), ECA (2016). Til að fá ákveðna uppbyggingu á upplýsingar pá hefur hugtakið Core \& More (C\&M) til að aðlaga upplýsingagöf fyrir hvert fyrirtæki og par með auka skýrleika. Skýrleiki upplýsinga er t.d. röðun, flokkun og framsetning í skýringum reikningsskila. C\&M er ekki ætlað að staðla upplýsingagjöf, hvort sem um er að ræða fjárhagslega eða ófjárhagslega upplýsingagjöf. Megintilgangur er að flokka upplýsingagjöf í kjarna (e. Core) og útskýringar (e. More) og einnig nota stafræna framsetningu á upplýsingum, Accountancy Europe (2018). Með pessu móti skapast betri uppbygging upplýsinga og par af leiðandi eykst gagnsæi. Sambærilegt verkefni er í gangi hjá IASB sem nefnist Disclosure Initiative sem hefur pað markmið að draga úr óparfa upplýsingum í ársreikningum og leyfa meira sjálfstæði, valkvæði, við uppröðun og birtingu á skýringum í reikningsskilum (IASB, 2017). IFRS hefur verið með verkefnið Better Communication in Financial Reporting í gangi og er megimarkmið par að auka valmöguleika í framsetningu upplýsinga í reikningsskilum og um leið gera pær skiljanlegri aflestrar (IFRS, 2017).

Gagnsæi er hluti af góðum stjórnarháttum, OECD birti 1999 reglur og leiðbeiningar er varðar góða stjórnarhætti og hugtakið gagnsæi er par á meðal. Í IV. kafla leiðbeininganna er fjallað um skýringar og gagnsæi. Tilgangur leiðbeininganna frá OECD er meðal annars að;

The OECD Principles of Corporate Governance form part of a broader international effort to promote increased transparency, integrity and the rule of law.

Mikilvægi gagnsæis hafði litið dagsins ljós 10 árum áður en óreiðan á fjármálamarkaðinum varð að veruleika, haustið 2008. Mikilvægi pess að gagnsæi sé til staðar í fjárhagsskýrslum fyrirtækja og par með í samfélaginu er vegna pess að gagnsæi er grunnurinn að heilbrigðum fjármálamarkaði. Í millitíðinni birti OECD/G20, 2015, nýja skýrslu par sem hugtökin gagnsæi, skýringar (e. disclosure) og ábyrgð stjórnar (e. responsibilities of the board) voru til umræðu. Par kemur fram mikilvægi pessara hugtaka á hinum almenna markaði sem og peim opinbera. Á vefriti OECD er fjallað um pann grunn sem gagnsæi hefur gagnvart samfélaginu sem heild 
Openness and transparency are key ingredients to build accountability and trust, which are necessary for the functioning of democracies and market economies.

Gagnsæi er ekki einungis að auka magn upplýsinga, heldur purfa pær m.a. að vera tímalegar, gagnlegar og áreiðanlegar. Gagnsæi hefur einnig pann eiginleika að verkferlar (e. processes) sem vænta má að notaðir verða séu pekktir fyrirfram. Priðji aðili sem les ársreikninga má vænta pess að sú aðferðafræði sem notuð er við gerð og framsetningu reikningsskila sé í samræmi við fyrri reikningsskil og alpjóðlegar reikningsskilareglur. Petta getur m.a. átt við um gangvirðismat eigna í reikningsskilum t.d. fasteignafélög.

Gagnsæi og reikningsskilaleg reikningsskilasyld (e. accountability) eru hugtök sem eru samofin og styrkja hvort annað (Lepadatu og Piranau, 2009). Gagnsæi vísar í umhverfi par sem upplýsingar, ákvarðanir og athafnir eru gerðar sýnilegar, aðgengilegar og skiljanlegar fyrir priðja aðila. Reikningsskil eiga að gefa glögga mynd (e. true and fair view) af rekstri, efnahag og sjóðstreymi. Pessi glögga mynd er nauðsynleg til pess að priðji aðili geti tekið upplýsta ákvörðun og viðeigandi aðgerðir sem byggjast á reikningsskilum.

Tilgáta H1: Gagnsæi með tillit til fjárhagsupplýsinga hefur ekki aukist með tilkomu endurskoðunarnefnda.

Markhópar eru annars vegar nefndarmenn í endurskoðunarnefndum og hins vegar ytri endurskoðendur, sem eru báði spurðir um pað hvort gagnsæi fjárhagsupplýsinga viðkomandi eininga, almennt séð, hafi breyst með tilkomu endurskoðunarnefnda?

Tilgátu H1 verður svarað með tveimur undirtilgátum:

Tilgáta 1.1. Раð er EKKI álit nefndarmanna í endurskoðunarnefndum að gagnsæi hafi breyst með tilliti til fjárhagsupplýsinga, almennt séð, með tilkomu endurskoðunarnefnda.

Tilgáta 1.2. Рað er EKKI álit ytri endurskoðenda að gagnsæi hafi breyst með tilliti til fjárhagsupplýsinga, almennt séð, með tilkomu endurskoðunarnefnda

\subsection{Traust}

Traust er mikilvægt hugtak í stjórnarháttum og viðskiptafræði almennt par sem pað getur bæði haft áhrif á skilvirkni í stjórnun og viðskiptum og haft áhrif til pess að draga úr áhættu og kostnaði (Frei og Morris, 2020; Poppo, Zhou og Ryu, 2008; Puranam og Vanneste, 2009). Traust hefur verið skilgreint með ýmsu móti en í tengslum við umboðskenningu er útgangspunkturinn að traust feli í sér ákveðnar væntingar sem draga úr hættu á pví að sá sem maður á í viðskiptum við hegði sér eins og tækifærissinni (Bradach og Eccles, 1989). Petta á við jafnvel og kannski sérstaklega pegar ekki er hægt að hafa eftirlit með viðkomandi (Mayer o.fl., 1995). Hugmyndin er að petta traust skapist frekar vegna reynslu af fyrri samskiptum aðila (Deutsch, 1973; Rempel, Holmes og Zanna, 1985) par sem reynsla og upplýsingar frá fyrri samskiptum gefa möguleika á að meta hegðun og ásetning og gefur tækifæri til pess að meta trúverðugleika aðila (Gulati og Sytch, 2008; Anderson og Weitz, 1989; Lindskold, 1978).

Endurskoðunarnefndir eru mikilvægur páttur í eftirlitskerfi stjórnarhátta og hugmyndin er að tilkoma endurskoðunarnefnda auki traust á eftirlitskerfinu. Traust á endurskoðunarnefndir og á milli aðila sem tengjast endurskoðunarnefndum auka jafnframt líkur á skilvirkni endurskoðunarnefnda (Puranam og Vanneste, 2009; DeZoort o.fl., 2002).

Tilgáta H2: Traust með tillit til fjárhagsupplýsinga hefur ekki aukist með tilkomu endurskoðunarnefnda.

Markhópar eru annars vegar nefndarmenn í endurskoðunarnefndum og hins vegar ytri endurskoðendur, sem eru báði spurðir um pað hvort traust á fjárhagsupplýsingum viðkomandi eininga, almennt séð, hafi breyst með tilkomu endurskoðunarnefnda? 
Tilgátu $\mathrm{H} 2$ verður svarað með tveimur undirtilgátum:

Tilgáta 2.1. Рað er EKKI álit nefndarmanna í endurskoðunarnefndum að traust hafi breyst með tilliti til fjárhagsupplýsinga, almennt séð, með tilkomu endurskoðunarnefnda.

Tilgáta 2.2. •að er EKKI álit ytri endurskoðenda að traust hafi breyst með tilliti til fjárhagsupplýsinga, almennt séð, með tilkomu endurskoðunarnefnda

\section{Aðferðafræðin}

Gerðar voru tvær kannanir, annars vegar á meðal nefndarmanna endurskoðunarnefnda árið 2016 og hins vegar á meðal ytri endurskoðenda árið 2018. Tilgangur með könnuninni frá 2016 var m.a. að fá upplýsingar um starfsumhverfi, umfang og viðhorf nefndarmanna endurskoðunarnefnda. Tilgangur með könnuninni frá 2018 var m.a. að fá upplýsingar um viðhorf til endurskoðunarnefnda er tengist vinnu ytri endurskoðenda. Greinin er fyrsta rannsókn á hugtökunum gagnsæi og traust með tilliti til fjárhagsupplýsinga vegna starfa endurskoðunarnefnda. Báðar kannanirnar voru gerðar í samstarfi við Félag löggiltra endurskoðenda (FLE).

Í könnun 2016 var sendur út spurningalisti til nefndarmanna í endurskoðunarnefndum er falla undir skilgreininguna „einingar tengdar almannahagsmunum“. Í spurningalistanum var óskað eftir upplýsingum um samsetningu og umfang endurskoðunarnefnda o.fl. í pví augnamiði að varpa ljósi par á. Jafnframt var óskað eftir upplýsingum um bakgrunn nefndarmanna, pekkingu, reynslu og viðhorf peirra til ýmissa hugtaka s.s. ábyrgð, gagnsæi og traust.

Í könnun 2018 var sendur út spurningarlisti til ytri endurskoðanda, félagsmanna FLE. Í spurningalistanum var óska m.a. eftir pví hvort viðkomandi hafi unnið við eða áritað ársreikning er tilheyrir einingu tengda almannahagsmunum. Í framhaldinu var spurt um viðhorf til ýmissa atriða er tengjast endurskoðunarvinnu og endurskoðunarnefnd viðkomandi einingar.

Hér er aðeins fjallað um afmarkaða pætti í pessum könnunum, p.e. gagnsæi og traust. Mikilvægi endurskoðunarnefnda hefur aukist með tímanum, m.a. með pá áherslu að nefndarmenn eru gæslumenn almennings pegar kemur m.a. að gagnsæi og gæðum fjárhagslegra upplýsinga sem stjórn viðkomandi félags leggur fram.

Samanburður á niðurstöðum pessara kannana er varða hugtökin, gagnsæi og traust, getur gefið ákveðna vísbendingu um pað hvort viðhorf meðal pátttakenda er líkt eða ólíkt. Virkni endurskoðunarnefnda sem og annara nefnda byggist oft á viðhorfi og eða áliti peirra einstaklinga sem sitja í nefndum og peirra sem starfa náið með endurskoðunarnefndum. Pví er mikilvægt að vita eða nálgast pá vitneskju um viðhorf pessara aðila, p.e. nefndarmanna og ytri endurskoðenda, með tilliti til hlutverks endurskoðunarnefnda.

\subsection{Pátttakendur}

Rannsóknaraðferðir geta verið mismunandi. Pær geta m.a. verið eigindlegar (e. qualitative) , megindlegar (e. quantitative) eða samsettar úr báðum. Val á aðferðafræði verður að taka hliðsjón af viðfangsefninu. Rannsóknin er megindleg og byggir á upplýsingaöflun í formi spurningakönnunar. Gagnasöfnun fer fram með nákvæmum og kerfisbundnum hætti og niðurstöður eru settar fram á tölfræðilegan hátt til að styðja eða hafna tilgátum (Ragnheiður Harpa Arnardóttir, 2013).

Við upphaf hverrar rannsóknarvinnu parf að ákveða stærð úrtaksins, hvort pað eigi að endurspegla allt pýðið eða ekki, einnig parf að ákveða hvaða tegund könnunar skuli notuð. Í pessu tilviki voru spurningar lagðar fyrir allt pýðið og svarhlutfallið notað til að álykta um heildina. Til pess að sá möguleiki væri fyrir hendi að endurtaka rannsóknina með sama hætti síðar var ákveðið að fara pá leið að notast við megindlegar rannsóknaraðferðir með stöðluðum spurningalistum og leggja fyrir allt pýðið (Bryman, 2008).

Niðurstöður og greining eru fengnar með fjölda svara sem mæld eru og athafnir bornar 
saman með tölfræðilegum og/eða myndrænum hætti. Kannanir (e. surveys) eru yfirleitt notaðar sem upplýsinga- og mælitæki. Aðferð pessi er valin par sem hún er bæði ódýr og nokkuð örugg. Aðferðin er notuð til nálgast upplýsingar og safna peim saman og með frekari úrvinnslu er hægt að stuðla að frekari pekkingarmyndun með gagnsæi og rökréttri greiningu miðað við pað viðfangsefni sem skoðað er hverju sinni. Pátttakendur fengu allir sama spurningalistann sendan með tölvupósti á netfang á vinnustaðnum, sem auðveldaði pátttakendum að svara könnuninni. Megindleg aðferðafræði er viðeigandi m.a. pegar verið er að skoða eitthvað sem hægt er að telja, vega eða mæla en sú aðferð er stöðluð og getur sýnt fram á mynstur í gögnum. Upplýsingum er safnað saman á tölulegu formi á hlutlægan hátt og er notast við tölulegar aðferðir við framsetningu og túlkun gagna (Ragnheiður Harpa Arnardóttir, 2013). Kostirnir eru að petta er tiltölulega einföld leið til gagnaöflunar, ekki parf að ná til fólks á tilteknum tíma, engar skekkjur verða vegna áhrifa spyrla og svarendur hafa betra næði til að svara (Churchill, 2002).

Við val á úrvinnslu var ákveðið að notast við lýsandi rannsókn (e. descriptive studies). Lýsandi rannsókn felur í sér að rannsaka breytur í úrtaki og leggja fram tölfræðilegar niðurstöður. Rannsóknir par sem upplýsingar eru fengnar með spurningakönnun frá einum hópi á sama tíma eru kallaðar pversniðsrannsóknir (e. cross-sectional). Kostir lýsandi rannsókna eru að pær geta safnað miklum upplýsingum til að hægt sé að gera yfirgripsmeiri rannsóknir í framhaldinu. Pó eru ákveðnir gallar við lýsandi rannsóknir, líkt og vöntun á dýpri skilningi á bak við einstök svör og upplifun pátttakenda. Pá geta spurningar verið of leiðandi, pannig að vanda verður orðalag spurninga (Ragnheiður Harpa Arnardóttir, 2013).

Hafa parf í huga að pað hafa ekki allir sömu forsendur til að svara spurningunum eða hafa sama skilning á efni spurningar (Bryman, 2008). Til pess að forðast misskilning á innihaldi spurninga eru pær hafðar eins skýrar og mögulegt er. Petta var gert til að takmarka skekkju af hálfu svarenda sem gæti myndast ef uppbygging spurningalistans er ekki nógu góð eða ef spurningarnar væru óskýrar eða leiðandi (Burns og Bush, 2006).

Spurningar í megindlegum könnunum eru almennt taldar réttmætar par sem sterk tengsl hafa mælst á milli pess sem fólk svarar í slíkum könnunum og pess sem pað gerir í raun. Megindleg aðferðafræði er talin heppileg par sem hún er formlegt, hlutbundið og kerfisbundið ferli sem hentar vel til að lýsa breytum og tengslum á milli peirra (Forlákur Karlsson 2003).

Ávallt parf að huga að pví að fá marktækar niðurstöður úr rannsókninni og pví parf að skoða réttmæti og áreiðanleika. Með réttmæti er átt við hvort að túlkun niðurstaðna er viðeigandi, hvort verið sé að draga réttar ályktanir og með áreiðanleika er átt við hvort hægt sé að endurtaka rannsóknina og fá svipaðar niðurstöður. Með áreiðanleika er stöðugleiki mældur og ef rannsóknin yrði endurtekin pá er hægt að sjá hvort hún skili álíka niðurstöðu. Ein leið við öflun gagna fyrir megindlega rannsókn er staðlaður spurningalisti og var einn slíkur notaður í pessari rannsókn (Sigurlína Davíðsdóttir, 2003).

Markhópar í pessari rannsókn voru tveir, annars vegar nefndarmenn í endurskoðunarnefndum á peim tíma (2016), sbr. skilgreininguna "eining tengd almannahagsmunum“, sbr. lög um endurskoðendur og hins vegar ytri endurskoðendur (2018). Fyllsta trúnaðar var gætt pannig að ekki verði hægt að rekja einstök svör til svarenda.

\subsection{Framkvæmdin}

Í könnun 2016 var haft samband við 133 einingar. Af peim svöruðu 77 aðilar fyrirspurnum og par af reyndust 47 einingar vera með endurskoðunarnefnd en 30 svör bárust um að engin nefnd væri starfandi. 56 einingar (42\%) sinntu ekki fyrirspurnum rannsóknarinnar. Alls söfnuðust 126 einstök tölvupóstföng hjá nefndarmönnum en nokkur dæmi voru um að einstaklingar sætu í fleiri en einni nefnd. Svör fengust frá 69 pátttakendum sem gerir um $55 \%$ svarhlutfall á meðal peirra nefndarmanna sem vísað var á. Skipting á milli kynjanna voru pannig: 58\% karlar og 42\% konur. Erfitt var að hafa upp á netföngum nefndarmanna 
endurskoðunarnefnda. Á heimasíðum viðkomandi eininga var oft ekki að finna hverjir sitja í endurskoðunarnefnd eða hvað pá netföng peirra, eða a.m.k. formannsins. Hér má segja að gagnsæi vantar m.t.t. hagsmunagæslu gagnvart priðja aðila.

peir lögaðilar sem falla undir lagalegu skilgreininguna „eining tengd almannahagsmunum“, sbr. lög um endurskoðendur, eru t.d. hlutafélög, sveitarfélög, stofnanir og lífeyrissjóðir. Aðferðafræðin var valin með pað fyrir augum að ná til sem flestra starfandi nefndarmanna endurskoðunarnefnda. Рað kom fram svo við nánari skoðun að margar einingar sem par voru skráðar reyndust heyra undir aðrar stærri einingar (t.d. dótturfélög) og voru pví ekki með sérstaka endurskoðunarnefnd á sínum vegum.

Í könnun 2018 var haft samband við endurskoðendur með aðstoð Félags löggiltra endurskoðenda (FLE). FLE sá um að senda póst til félagsmanna sinna og sent var til 388 aðila, 285 karla (73\%) og 103 kvenna (27\%). Af peim voru 261 starfandi á endurskoðunarstofu en 127 utan. Fjöldi pátttakenda sem hóf könnuninni var 110 en alls luku 77 peirra við hana. Svarhlutfall var pví um 20\% af pýðinu (388) eða 29,5\% starfandi á endurskoðunarskrifstofu. Helstu bakgrunnseinkenni pátttakenda voru að 69\% voru karlar og 31\% konur, 55\% voru á aldrinum 41-60 ára en 31\% var á aldrinum 31-40 ára og 13\% 61 árs eða eldri. Aðeins einn pátttakandi var 30 ára eða yngri. Alls höfðu 56\% starfað sem endurskoðendur í 16 ár eða lengur, aðrir skemur.

Til að fá betra undirlag varðandi hvort tilgátu verður hafnað eða ekki pá er fimm stiga Likert skalanum breytt úr texta yfir í tölugildi. „Aukist til muna“ fær gildið 1, sem er jákvæðasta gildið og „Minnkað til muna“ fær gildið 5, sem er neikvæðasta gildið (Warmbrod, 2014). Framsetning gagna par sem Likert skala er breytt í tölugildi er notast við vegið meðaltal (Soffía Halldórsdóttir o.fl., 2020) ásamt staðalfráviki og 95\% öryggisbili.

\section{Niðurstöður}

\subsection{Gagnsæi}

Nefndarmenn í endurskoðunarnefndum ættu að vera í hvað bestri aðstöðu til að meta hvort gagnsæi á fjárhagsupplýsingar hafi breyst eða ekki með tilkomu endurskoðunarnefnda. Nefndarmenn hafa einna bestu innsýn í m.a. umfang, verkferla og pau efnisatriði er tekin eru fyrir, sem og úrvinnsla peirra. Nefndarmenn hafa aðgang að öllum innri upplýsingum og einnig aðgang að ytri upplýsingum er tengjast fjárhag. Рað sama má segja um ytri endurskoðendur sem hafa sama aðgang og par að auki ákveðna fagmenntun í reikningsskilum og endurskoðun. Niðurstöður hér ættu pví að endurspegla raunstöðu á aðstæðum er tengjast endurskoðunarnefndum og gagnsæi með tilliti til fjárhagsupplýsinga.

Í spurningunum um gagnsæi fjárhagsupplýsinga, almennt séð, voru uppgefnir fimm möguleikar, skali með hugtökum; aukist til muna, aukist eitthvað, hvorki aukist eða minnkað, minnkað eitthvað og minnkað til muna. Yfirfært í tölugildi, 1, 2, 3, 4 og 5. Ekkert svar var í „minnkað eitthvað“ eða „minnkað til muna“.

Eftirfarandi tilgátur voru prófaðar:

Tilgáta 1.1. Рað er EKKI álit nefndarmanna í endurskoðunarnefndum að gagnsæi hafi breyst með tilliti til fjárhagsupplýsinga, almennt séð, með tilkomu endurskoðunarnefnda.

Tilgáta 1.2. Рað er EKKI álit ytri endurskoðenda að gagnsæi hafi breyst með tilliti til fjárhagsupplýsinga, almennt séð, með tilkomu endurskoðunarnefnda

Niðurstöður úr pessum tveimur tilgátum, 1.1 og 1.2 eru samhljóða. Рað er hægt að hafna pví að sé EKKI álit nefndarmanna og ytri endurskoðenda, að gagnsæi hafi breyst með tilliti til fjárhagsupplýsinga, almennt séð, með tilkomu endurskoðunarnefnda Með pessa niðurstöður að leiðarljósi pá er aðaltilgátunni H1 hafnað, p.e. að gagnsæi hefur ekki aukist með tilkomu endurskoðunarnefnda. Rúmlega 37.7\% af ytri endurskoðendum, sjá mynd 1, höfðu pað álit að gagnsæi með tilliti til fjárhagsupplýsinga breytist ekki vegna starfa endurskoðunarnefnda. Nefndarmenn endurskoðunarnefnda með sömu afstöðu voru um 
22,4\%. Meðaltal pessara tveggja markhópa var um 31,1\%, sem álitu að engin breyting hefði orðið. Petta álit liggur fyrir prátt fyrir að endurskoðunarnefndir hafa verið virkar í um tíu ár.

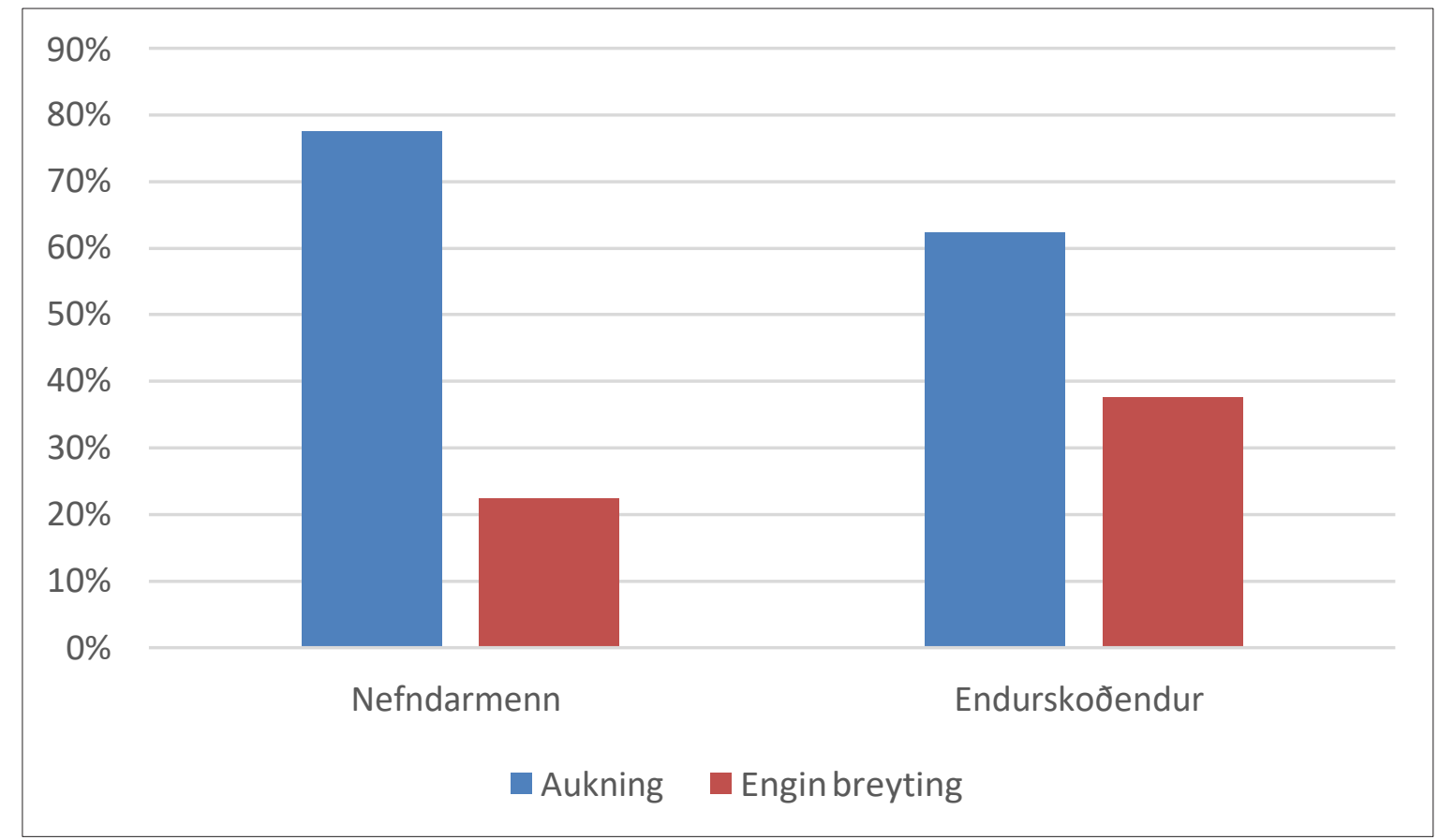

Mynd 1. Hlutfallsleg skipting milli markhópa m.t.t. gagnsæis.

Hvað varðar tilgátu 1.1 er vegið meðaltal 2,069, pví nær einum pví meiri samhljómur í áliti um að gagnsæi m.t.t. fjárhagsupplýsinga hafi aukist til muna. Staðalfrávik er 0,617 og 95\% öryggisbil 1,910 til 2,228. Hvað varðar tilgátu 1.2 er vegið meðaltal 2,286. Staðalfrávik er 0,625 og 95\% öryggisbil 2,146 til 2,425. Fyrirtæki sem skilgreind eru sem einingar tengdar almannahagsmunum voru skyldug að innleiða endurskoðunarnefndir frá og með árinu 2009. Hlutverk endurskoðunarnefnda var m.a. að auka gagnsæi og bæta upplýsingaumhverfi fyrirtækja sem eru pjóðhagsleg mikilvæg. Enn er nokkuð í land að peir aðilar sem vinna einna næst endurskoðunarnefndum séu samhljóða í pví að gagnsæi hafi aukist með tilkomu nefndanna.

\subsection{Traust}

Nefndarmenn í endurskoðunarnefndum ættu að vera í hvað bestri aðstöðu til að meta hvort traust á fjárhagsupplýsingar hafi breyst eða ekki, með tilkomu endurskoðunarnefnda. Nefndarmenn hafa einna best innsýn í m.a. umfang, verkferla og pau efnisatriði er tekin eru fyrir, sem og úrvinnsla peirra. Nefndarmenn hafa aðgang að öllum innri upplýsingum og einnig aðgang að ytri upplýsingum er tengjast fjárhag. Рað sama má segja um ytri endurskoðendur sem hafa sama aðgang og par að auki ákveðna fagmenntun í reikningsskilum og endurskoðun. Niðurstöður hér ættu pví að endurspegla raunstöðu á aðstæðum er tengjast endurskoðunarnefndum og trausti með tilliti til fjárhagsupplýsinga.

Í spurningunum um traust á fjárhagsupplýsingum, almennt séð, voru uppgefnir fimm möguleikar, skali með hugtökum; aukist til muna, aukist eitthvað, hvorki aukist eða minnkað, minnkað eitthvað og minnkað til muna. Yfirfært í tölugildi, 1, 2, 3, 4 og 5.

Eftirfarandi tilgátur voru prófaðar:

Tilgáta 2.1. Pað er EKKI álit nefndarmanna í endurskoðunarnefndum að traust hafi breyst með tilliti til fjárhagsupplýsinga, almennt séð, með tilkomu endurskoðunarnefnda. 
Tilgáta 2.2. Рað er EKKI álit ytri endurskoðenda að traust hafi breyst með tilliti til fjárhagsupplýsinga, almennt séð, með tilkomu endurskoðunarnefnda

Niðurstöður úr pessum tveimur tilgátum, 2.1 og 2.2 eru samhljóða. Рað er hægt að hafna pví að sé EKKI álit nefndarmanna og ytri endurskoðenda, að traust hafi breyst með tilliti til fjárhagsupplýsinga, almennt séð, með tilkomu endurskoðunarnefnda Með pessa niðurstöður að leiðarljósi pá er aðaltilgátunni $\mathrm{H} 2$ hafnað, p.e. að gagnsæi hefur ekki aukist með tilkomu endurskoðunarnefnda. Rúmlega $41 \%$ af ytri endurskoðendum, sjá mynd 2, höfðu pað álit að traust með tilliti til fjárhagsupplýsinga breytist ekki vegna starfa endurskoðunarnefnda. Nefndarmenn endurskoðunarnefnda með sömu afstöðu voru um 38\%. Meðaltal pessara tveggja markhópa var um 39,5\%. Petta álit liggur fyrir prátt fyrir að endurskoðunarnefndir hafa verið virkar í um tíu ár.

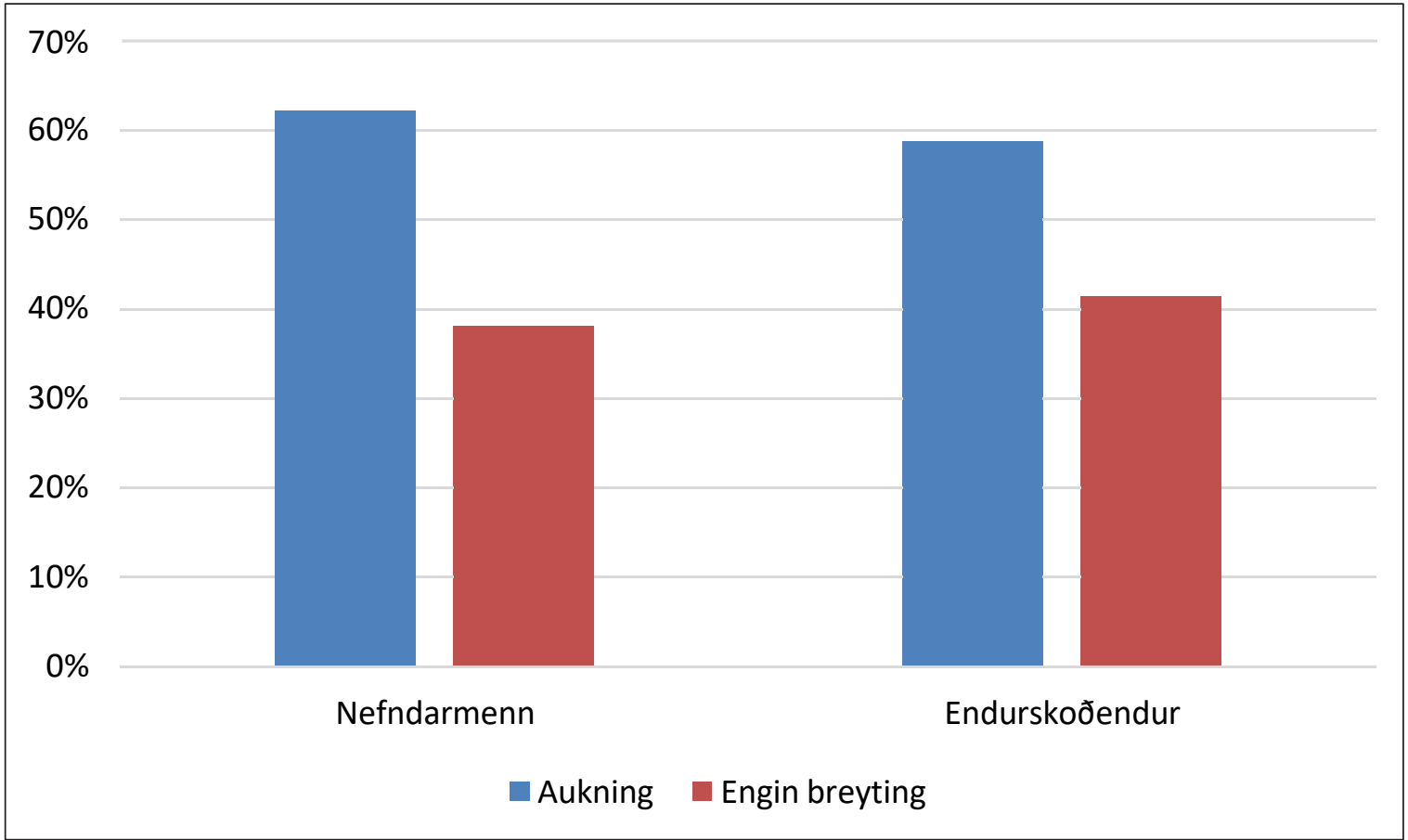

Mynd 2. Hlutfallsleg skipting á milli markhópa m.t.t. trausts.

Um $60 \%$ peirra sem tóku afstöðu álitu að traust hefði aukist með störfum endurskoðunarnefnda m.t.t. fjárhagsupplýsinga. Hvað varðar tilgátu 2.1 er vegið meðaltal 2,310, pví nær einum pví meiri samhljómur í áliti um að traust m.t.t. fjárhagsupplýsinga hafi aukist til muna. Staðalfrávik er 0,598 og 95\% öryggisbil 2,156 til 2,464. Hvað varðar tilgátu 2.2 er vegið meðaltal 2,316. Staðalfrávik er 0,637 og 95\% öryggisbil 2,173 til 2,459. Fyrirtæki sem skilgreind eru sem einingar tengdar almannahagsmunum voru skyldugar að innleiða endurskoðunarnefndir frá og með árinu 2009. Hlutverk endurskoðunarnefnda var m.a. að auka traust og bæta upplýsingaumhverfi fyrirtækja sem eru pjóðhagsleg mikilvæg. Enn er nokkuð í land að peir aðilar sem vinna einna næst endurskoðunarnefndum séu samhljóða í pví að traust hafi aukist með tilkomu nefndanna.

\section{Umræour}

Traust og gagnsæi eru lykilhugtök hvað varðar fyrirtækjarekstur, fjármálastjórnun og endurskoðun. Endurskoðunarnefndir hafa pað hlutverk að auka traust og gagnsæi á fjárhagsupplýsingum. Niðurstöður rannsóknarinnar benda til pess að meirihluti nefndarmanna endurskoðunarnefnda og ytri endurskoðendur eru sammála um að gagnsæi og traust hefur aukist með tilkomu endurskoðunarnefnda. Pað kemur ekki á óvart!

Рað sem kemur hins vegar á óvart er að niðurstaðan sé ekki meira afgerandi. Pað er 
athyglisvert að $41 \%$ ytri endurskoðenda telja að traust hafi ekki aukist og $38 \%$ að gagnsæi hafi ekki aukist. Jafnframt er pað ekki síður athyglisvert að niðurstaðan er ekki meira afgerandi hvað varðar áhrif endurskoðunarnefnda á traust og gagnsæi fjárhagsupplýsinga en $38 \%$ nefndarmanna sjálfra telja að traust hafi ekki aukist og $22 \%$ að gagnsæi hafi heldur ekki aukist. Útskýringin kann að vera sú að flókið samspil stjórnarhátta eða peirrar umgjarðar sem er um stjórnarhætti dragi úr trausti og jafnvel gagnsæi frekar en að auka pað (Malhotra og Murnigham, 2002; Puranam og Vanneste, 2009). Hugtökin tengjast pví við stjórnarhætti og fjárhagsupplýsingagjöf og hefur par með áhrif á skilvirkni í stjórnun og í viðskiptum, par með er dregið úr áhættu og kostnaði við rekstur, petta er í beinum tengslum við umboðskenningar. Rannsóknin staðfestir par af leiðandi að hagaðilar hafa pá skoðun að endurskoðunarnefndir hafi pjónað tilgangi sínum að pví leyti að pær auka traust og gagnsæi fjárhagsupplýsinga.

Möguleg skýring á pessu samstíga áliti nefndarmanna og ytri endurskoðenda er að flestallir ef ekki allir eru langskólagengnir og störf peirra, nefndarmanna og endurskoðenda, eru sérhæf á ákveðnu afmörkuðu starfssviði. Petta má heimfæra á Carcello o.fl. (2002) um faglega dómgreind. Petta eru atriði sem pyrfti að skoða betur.

Annað atriði sem gæti haft áhrif á svör er hvernig hver og einn skilgreinir hugtökin gagnsæi og traust. Pví til viðbótar er möguleg tilfinning á pví hvað er aukning og hvað er engin breyting. Hægt er að athuga pessa afstöðu með eigindlegri rannsókn.

Priðja atriðið sem væri áhugavert að skoða er hvaða álit priðji aðili hefur gagnvart pessum hugtökum, gagnsæi og traust. Með priðja aðila er átt við pá aðila sem nota og lesa reikningsskil fyrirtækjanna, p.e. haghafar í breiðum skilningi. Pað er ekki nóg að nefndarmenn eða endurskoðendur séu ánægðir með starf endurskoðunarnefnda ef haghafar telja að starf endurskoðunarnefnda skipti engu máli hvað varðar gagnsæi og traust með tilliti til fjárhagsupplýsinga, reikningsskila, eininga tengda almannahagsmunum.

Rannsóknir á endurskoðunarnefndum einskorðast ekki einungis við gæði reikningsskila, heldur hefur áhugi á peim einnig beinst að aukum áhyggjum tengt stjórnarháttum sem og fjármálaupplýsingum fyrirtækja (DeZoort o.fl., 2002; Pomeroy og Thornton, 2008).

Раð væri áhugavert að gera pannig fleiri rannsóknir sem skoða traust og gagnsæi á fjárhagsupplýsingum enda eru pessi hugtök grundvallaratriði í viðskiptum og stjórnarháttum. Mikilvægt er að í framhaldinu verði gerðar rannsóknir byggðar á eigindlegri aðferðafræði par sem viðtöl við nefndarmenn, endurskoðendur og greiningaraðila og tengda aðila eru notuð til pess að fá dýpri innsýn í störf endurskoðunarnefnda á Íslandi.

\section{Heimildir}

Abernathy, John L., Kang, Tony og Krishnan, Gopal, (2011). Audit Committee Expertise and Financial Analysts' and Investors' Ability to Anticipate Future Earnings. Aðgengilegt SSRN: https://ssrn.com/abstract=1942928 or http://dx.doi.org/10.2139/ssrn.1942928

ACCA. (2008). The Association of Chartered Certified Accountants. Complexity in Financial Reporting. London WC2A 3EE United Kingdom

ACCA. (2014). The Association of Chartered Certified Accountants. Enhancing the value of the audit committee report. London WC2A 3EE United Kingdom

Accountancy Europe. (2018, 30. júní). The reporting times: Smarter corporate reporting with CORE \& MORE. https://www.accountancyeurope.eu/reporting-transparency/smater-corportare-reporting-core-more/

Ajinkya, B., Bhojraj, S., og Sengupta, P,. (2005). The association between outside directors, institutional investors and the properties of management earnings forecasts. Journal of Accounting Research, 43 (2005), 343-376

Anderson, E., og Weitz, B. (1989). Determinants of continuity in conventional industrial channel dyads. Marketing Science, 8: 310-323.

Ball, C. (2009). What is Transparency? Public Integrity, September 2009. doi:10.2753/PIN1099-9922110400.

Beasley, M. S., Carcello, J. V., Hermanson, D. R. og Neal, T. L. (2009) The audit committee oversight process, Contemporary Accounting Research, 26(1), 65-122.

Ashbaugh-Skaife, H., Collins, D.W. og Kinney, W. (2008) The Effect of SOX Internal Control Deficiencies and Their Remediation on Accrual Quality. The Accounting Review, 83, 217-250.

https://doi.org/10.2308/accr.2008.83.1.217 
Berle, A. A. og Means, G. G. $(1932,1968)$. The Modern Corporation and Private Property. New York: Macmillan.

Bradach, J. L., og Eccles, R. G. (1989). Price, authority, and trust-From ideal types to plural forms. Annual Review of Sociology, 15: 97-118.

BRC, (1999). Blue Ribbon Committee on Improving the Effectiveness of Corporate Audit Committees. (1999). Report and recommendations of the Blue Ribbon Committee on Improving the effectiveness of corporate audit committees. New York, NY: New York Stock Exchange and National Association of Securities Dealers.

Bryman, A. (2008). Social Research Methods (3rd Ed.). New York: Oxford University Press.

Burke, F. M. og D. M. Guy. (2001). Audit committees: A guide for directors, management, and consultants. New York: Aspen Law \& Business.

Burns, A. C. og Bush, R. F. (2006). Marketing Research. New Jersey: Pearson Education Inc.

Bushman, R., Piotroski, J. og Smith, A. (2004). What Determines Corporate Transparency? Journal of Accounting Research, Vol. 42 No. 2 May 2004, pp. 207-252.

Carcello, J.V., Hermanson, R. D. og Neal, T. L. (2002). Disclosures in Audit Committee Charters and Reports. Accounting Horizons (2002) 16 (4): 291-304. doi.org/10.2308/acch.2002.16.4.291

CAQ. (2019, nóvember). Audit Committee Transparency Barometer. Center for Audit Quality. https://www.thecaq.org/

Churchill, G. A. (2002). Marketing Research: Methodological foundations. Fort Worth: Harcourt College Publishers.

Dasgupta, S., Gan, J., og Gao, N. (2010). Transparency, Price Informativeness, and Stock Return Synchronicity: Theory and Evidence. Journal of Financial and Quantitative Analysis, 45(5), 1189-1220. doi:10.1017/ S0022109010000505

Deutsch, M. (1973). The resolution of conflict. New Haven, CT: Yale University Press.

DeZoort, F. T., Hermanson, D., Archambeault, D. og Reed, S. (2002) 'Audit committee effectiveness: A synthesis of the empirical audit committee literature', Journal of Accounting Literature, 21, 38-75.

ECA. (2016). Auditors role on promoting transparency and accountability. Workshop 25 - 26 January 2016. https:// www.eca.europa.eu/Lists/ECADocuments/WORKSHOP_ON_PUBLIC_SECTOR_ACCOUNTING/ECA_ Workshop_on_public_sector_accounting_A_Popovic.pdf

Einar Guðbjartsson, Eypór Í. Jónsson, og Jón S. Snorrason, (2018). Endurskoðunarnefndir: Samsetning og góðir stjórnarhættir. Tímarit um viðskipti og efnahagsmál, 15(2): 73-95.

EU. (2014). Directive 2014/56/EU of the European Parliament and of the Council. http://eur-lex.europa.eu/ legal-content/EN/TXT/?uri=celex\%3A32014L0056

EU. (2016). European Commission, Reform of the EU Statutory Audit Market.

EU. (2019). European Commission, Guidelines on non-financial reporting. Supplement on reportin climate-related information.

Fama, E.F. (1980). Agency Problems and the Theory of the Firm. Journal of Political Economy, 88(2): 288-307.

Fama, E.F. og Jensen, M. (1983). Separation of ownership and control. Journal of Law and Economics, 26: 301-325.

FEI. (2010). Financial Executives International. The role of disclosures in the financial statements of private business in accessing credit. Canada, ISBN978-0-98909715-7-6

Finkelstein, S. (1992). Power in top management teams: dimensions, measurement and validation. Academy of Management Journal, 35, 3: 505-538.

Frankel og Li, 2004. Characteristics of a firm's information environment and the information asymmetrybetween insiders and outsiders. Journal of Accounting and Economics 37, 229-259.

Frei, F. og Morriss, A. (2020). Begin with Trust. Harvard Business Review, May-June 2020, pp. 112 - 121.

Ghosh, T. (2019). Corporate Governance and Audit Fees Evidence from Bangladeshi Listed Banks and NBFIs. Journal of Corporate Governance Research, Vol. 3 (1).

Gulati, R., Lawrence, P. R., og Puranam, P. (2005). Adaptation in vertical relationships: Beyond incentive conflict. Strategic Management Journal, 26: 415-440.

Gulati, R., og Sytch, M. (2008). Does familiarity breed trust? Revisiting the antecedents of trust. Managerial and Decision Economics, 29: 165-190.

Hambrick, D. C. og Mason, P. A. (1984) 'Upper echelons: The organization as a reflection of its top managers', The Academy of Management Review, 9(2), 193-206.

ICAW og PwC. (2015). Trust in public finances: A survey of citizens in 10 European countries. 1040 Brussels, Belgium

IASB. (2017, mars). Disclosure Initiative-Principles of Disclosure. International Accounting Standard Board. IASB, UK. https://www.ifrs.org/projects/2019/principles-of-disclosure/

IASB (2018). Conceptual Framework for Financial Reporting. International Accounting Standards Board. IASB, IFRS Foundation.

IFRS. (2017). Better Communication in Financial Reporting Making disclosures more meaningful. International Financial Reporting Standards Foundation, UK.

IFRS. (2018). Why global accounting standards? International Financial Reporting Standards Foundation, UK.https://www.ifrs.org/use-around-the-world/why-global-accounting-standards/\#case-for.

Jensen, M.C. og Meckling, W.H. (1976). Theory of the Firm, Managerial Behaviour, Agency Costs and Ownership Structure, Journal of Financial Economics, October: 305-60. 
Jo og Kim, (2007). Disclosure frequency and earnings management. Journal of Financial Economics, Vol. 84, no. 2, (2007).doi:10.1016/j.jfineco.2006.03.007

Kelton, S. A., og Yang, Ya. (2008). The impact of corporate governance on Internet financial reporting. Journal of Accounting and Public Policy 27(1), Jan.-Feb., 62-87. doi.org/10.1016/j.jaccpubpol.2007.11.001

Kirkpatrick, G. (2009). The corporate governance lessons from the financial crisis. Financial Market Trends OECD 2009.

Lin, J. W., Li, J. F. og Yang, J. S. (2006) ‘The effect of audit committee performance on earnings quality', Managerial Auditing Journal, 21(9), 921-933.

Lindskold, S. (1978). Trust development, the GRIT proposal, and the effects of conciliatory acts on conflict and cooperation. Psychological Bulletin, 88: 772-793

Lubatkin, M. (2007). One More Time: What is a Realistic Theory of Corporate Governance? Journal of Organisational Behaviour, 28: 59-67. pp.101-108.

Lepadatu, V. G. og Pirnau, M., (2009). Transparency in Financial Statements (IAS/IFRS). European Research Studies, 12(1).

Lög um ársreikninga, nr. 3/2006. https://www.althingi.is/lagas/nuna/2006003.html

Lög um endurskoðendur og endurskoðun, nr. 94/2019. https://www.althingi.is/ lagas/nuna/2019094.html

Malhotra, D., og Murnighan, J. K. (2002). The effects of contracts on interpersonal trust. Administrative Science Quarterly, 47: 534-559.

Mayer, R. C., Davis, J. H., og Schoorman, F. D. (1995). An integrative model of organizational trust. Academy of Management Review, 20: 709-734.

OECD. (1999). Principles of Corporate Governance. OECD Publications.

OECD/G20.(2015).PrinciplesofCorporateGovernance.OECDPublications.http://dx.doi.org/10.1787/9789264236882en.

OECD, Openness and Transparency - Pillars for Democracy, Trust and Progress. By Angel Gurría, OECD Secretary-General. https://www.oecd.org/unitedstates/opennessandtransparency-pillarsfordemocracytrustandprogress.htm

Pomeroy, B. og Thornton, D.B. (2008). Meta-analysis and the Accounting Literature: The Case of Audit Committee Independence and Financial Reporting Quality. European Accounting Review. 17(2), 305-330.

Poppo, L., og Zenger, T. (2002). Do formal contracts and relational governance function as substitutes or complements? Strategic Management Journal, 23: 707-725.

Poppo, L., K. Zhou, og S. Ryu (2008). Alternative origins to interorganizational trust: An interdependence perspective on the shadow of the past and the shadow of the future. Organization Science, 19(1): 39-55.

Puranam, P. og Vanneste, B (2009). Trust and Governance: Untangling a Tangled Web. Academy of Management Review, 34(1), 11 - 31.

Ragnheiður Harpa Arnardóttir. (2013). Megindlegar rannsóknir: Gerð rannsóknaráætlunar og yfirlit yfir helstu rannsóknarsnið. Í Sigríður Halldórsdóttir (ritstjóri), Handbók í aðferðafræði rannsókna (bls. 377-392). Akureyri: Háskólinn á Akureyri.

Rempel, J.K.,Holmes,J.G. og Zanna,M.P.(1985).Trustinclose relationships. Journal of Personality and Social Psychology, 49: 95-112.

Rittenberg, L. E. og R. D. Nair. (1993). Improving the effectiveness of audit committees. Montvale, NJ: Institute of Management Accountants.

SEC. (2002, September). Strengthening the Commission's Requirements Regarding Auditor Independence. https://www.sec.gov/rules/proposed/33-8154.htm

Sharma, V., Naiker, V. og Lee, B. (2009) 'Determinants of audit committee meeting frequency: Evidence from a voluntary governance system', Accounting Horizons, 23(3), 245-263.

Soffía Halldórsdóttir, Auður Hermannsdóttir og Kári Kárason. (2020). Klædd eða nakin? Áhrif nektar á viðhorf til auglsýsinga. Tímarit um viðskipti og efnahagsmál, 17 (1), 1-14.

Sigurlína Davíðsdóttir. (2003). Eigindlegar eða megindlegar rannsóknaraðferðir. Í Sigríður Halldórsdóttir og Kristján Kristjánsson (ritstjórar), Handbók i aðferðafræði og rannsóknum í heilbrigđisvísindum (bls. 219-235). Akureyri: Háskólinn á Akureyri.

http://europa.eu/rapid/press-release_MEMO-16-2244_en.htm

Stiles, P. og Taylor, B. (2001). Boards at Work - How Directors View their Roles and Responsibilities. Oxford: Oxford University Press.

Turley, S. og Zaman, M. (2007). Audit committee effectiveness: informal processes and behavioural effects. Accounting, Auditing \& Accountability Journal, 20(5), 765-788. doi.10.1108/09513570710779036

Udueni, H. (1999) Power dimensions in the board and outside director independence: Evidence from large industrial UK firms, Corporate Governance: An International Review, 7(1), 62.

Ulhøi, J.P. (2007). Revisiting the Principal-Agent Theory of Agency: Comments on the Firm-Level and Cross-National Embeddedness Theses. Journal of Organizational Behaviour, 28: 75-80.

Wang, M., Lee, M., og Chuang, J. (2016). Relations among audit committee establishment, information transparency and earnings quality: evidence from simultaneous equation models. Quality \& Quantity 50, 2417-2431. doi. org/10.1007/s11135-015-0269-y 
Warmbrod, J. Robert. (2014). Reporting and Interpreting Scores Derived from Likert-type Scales. Journal of Agricultural Education, 2014, 55(5), 30-47. doi: 10.5032/jae.2014.0503030.

Williamson, O. E. (1991). Comparative economic organization: The analysis of discrete structural alternatives. Administrative Science Quarterly, 36: 269-296.

Woolthuis, R. K., Hillebrand, B. og Nooteboom, B. (2005). Trust, contract and relationship development. Organization Studies, 26: 813-841.

Porlákur Karlsson. (2003). „Spurningakannanir: Uppbygging, orðalag og hættur“. Í Sigríður Halldórsdóttir og Kristján Kristjánsson (ritstjórar), Handbók i aðferðafræði og rannsóknum i heilbrigðisvísindum. Akureyri: Háskólinn á Akureyri. 